\title{
REVIEW
}

\section{Role of viruses in the induction of skin tumours and tumour-like proliferations of fish}

\author{
Kerstin Anders ${ }^{1, *}$, Mamoru Yoshimizu ${ }^{2, * *}$ \\ ${ }^{1}$ Institut für Meereskunde, Düsternbrooker Weg 20, D-24105 Kiel, Germany \\ ${ }^{2}$ Laboratory of Microbiology, Faculty of Fisheries, Hokkaido University, Minato 3-1-1, Hakodate, Hokkaido 041 Japan
}

\begin{abstract}
Skin tumours of fish are easily recognizable lesions, some of which have been known for centuries. Causes of fish tumour formation are varied and are often proposed to be multifactorial. In more than half of all cases examined by electron microscopy and virological methods, virus or virus-like particles were found in tumour tissues. So far, oncogenicity has been clearly demonstrated only for herpesviruses isolated from benign tumours. Classification of fish skin tumours, tumour-associated and tumour-inducing viruses, and the possible reasons for seasonal variation in skin tumour prevalence, are reviewed. It is postulated that fundamental principles determine the role of viruses in the induction of skin tumours of fish within a framework of different biological and environmental parameters.
\end{abstract}

KEY WORDS: Fish viruses · Skin tumours · Oncogenicity · Review

\section{INTRODUCTION}

Due to their distinctive appearance and obvious pathological nature, tumours ${ }^{1}$ of fish have been recognized by experts and laymen for centuries. Indeed, one of the first scientific documentations of a diseased fish concerned a Chaetodon species with tumour-like growths in the bones (Bell 1793). The author, a physician, wrote, 'The fishermen told me that the tumours were always found in the fish; I therefore conclude them to be natural to it'. Although no present day oncologist would confirm this statement, the nature and etiology of fish tumours are still poorly understood.

Published findings relating to fish tumours are widely scattered in the scientific literature. Comprehensive reviews on their classification have been given by Plehn (1910), Thomas (1931), Schlumberger \& Lucké (1948), Mawdesley-Thomas (1975), Dawe \& Harshbarger (1975), Budd \& Roberts (1978) and Möller

\footnotetext{
- Present address: Bundesministerium für Umwelt, Naturschutz und Reaktorsicherheit, Referat WA I 1 (M), Postfach 120629, D-53048 Bonn, Germany

*Addressee for correspondence
}

\& Anders (1986). Harshbarger (1984) reviewed different types of pseudotumours occurring in ectothermic animals, including fish, and Anon. (1984), Couch \& Harshbarger (1985) and Mix (1986) gave overviews of associations between cancerous diseases in aquatic animals and anthropogenic pollutants.

The largest registry of tumours in lower animals (RTLA) was established at the Smithsonian Institution in Washington, DC, USA, in 1965 (Harshbarger 1977, Harshbarger et al. 1981). To date, more than 50 basic types of tumours, ranging from benign epidermal papillomas to metastatic melanomas and hepatocellular carcinomas in more than 300 species of fish, have been registered. Among these, tumours of the skin comprise the largest group, accounting for

\footnotetext{
${ }^{1}$ In the text, except where stated otherwise, the term 'tumour' refers to both 'hyperplasia' and 'neoplasia' (the latter term being synonymous with 'tumour' in current medical literature) taking into account that hyperplasia and neoplasia are distinctly different processes (hyperplasia: increase in normal cell numbers that continues for only as long as the stimulus is present; neoplasia: increase in abnormal or autonomous, i.e. neoplastically transformed, cells which continues even after the stimulus disappears)
} 


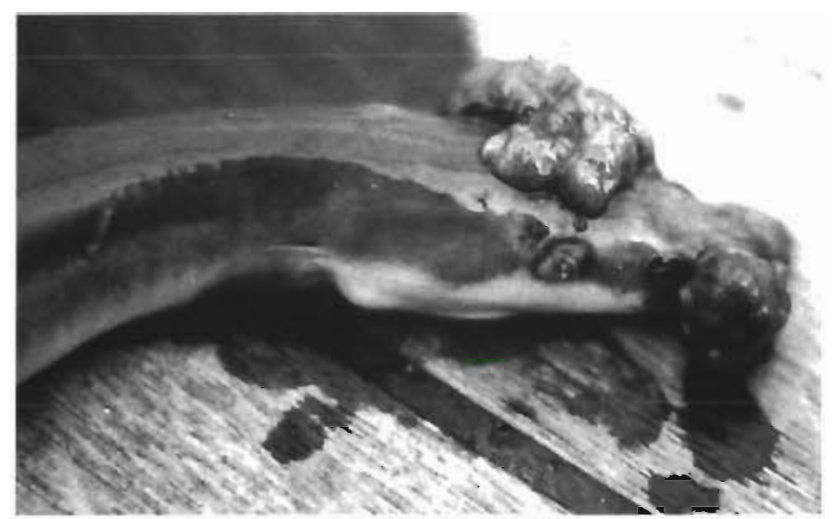

Fig. 1. Anguilla anguilla. European eel from the Elbe estuary (Germany) with extensive papillomatous growths on head and jaws (Anders 1088) roughly $50 \%$ of all cases registered (Harshbarger pers. comm.).

Depending upon season and geographical location, certain types of skin tumours may occur at high prevalences in wild fish such as European eel Anguilla anguilla (Fig. 1), dab Limanda limanda (Fig. 2a), European smelt Osmerus eperlanus (Fig. 3a, b), and northern pike Esox lucius from NE Atlantic coastal areas (Möller 1979, Dethlefsen 1990, Möller \& Anders 1992). While the occurrence of 'carp-pox' lesions in cultured cyprinids has decreased in importance, new tumourous conditions which have appeared in cultured lake trout Salvelinus namaycush and Japanese flounder Paralichthys olivaceus (Fig. 4c) have con. tributed to high mortalities among larvae and juvenile specimens.
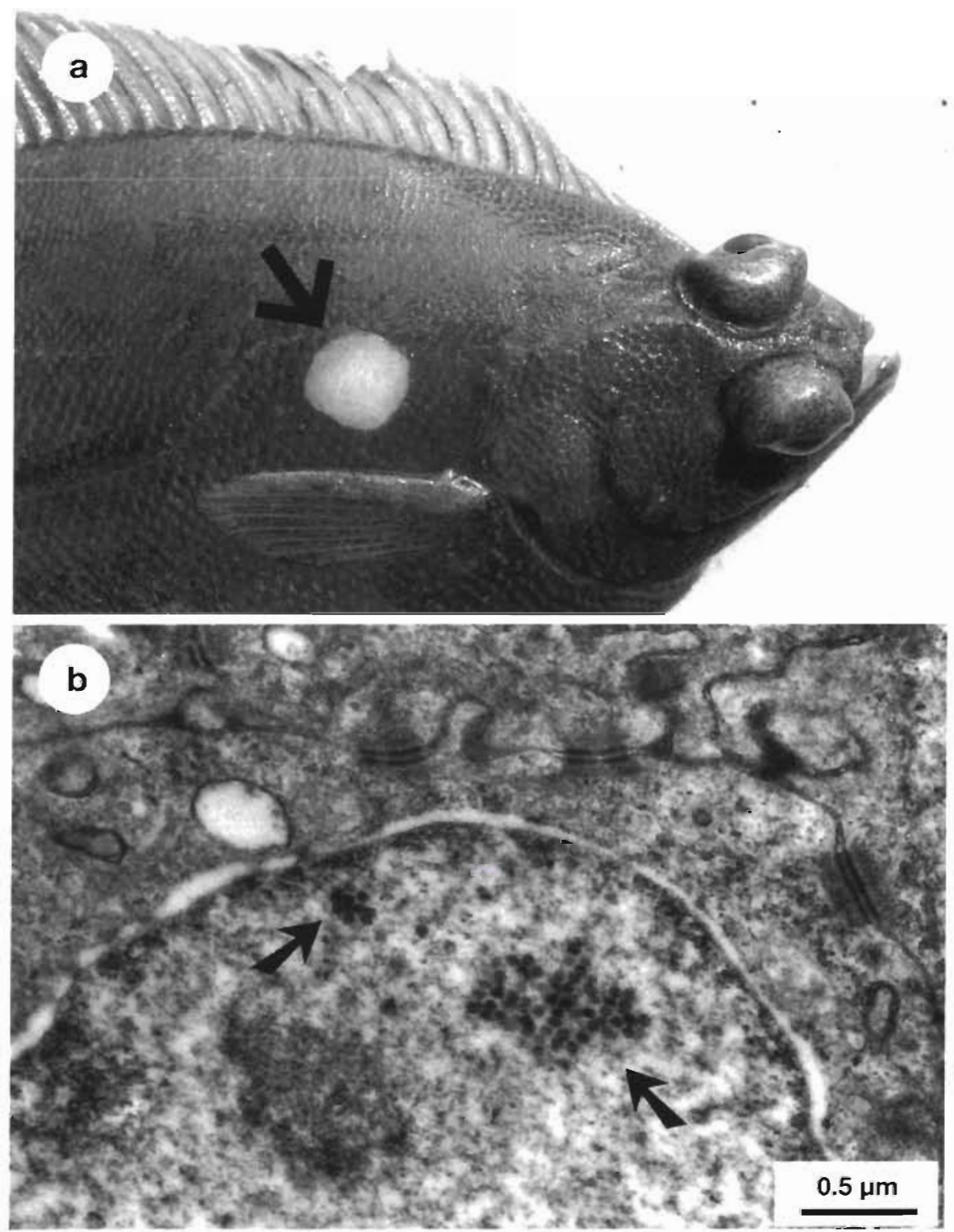

Fig. 2. Limanda limanda. Epidermal papillomas in dab from the German Wadden Sea. (a) A typical rounded flat epidermal papilloma on the body surface (Anders 1988); (b) aggregation of adenovirus-like particles (arrows) in the nucleus of a papilloma cell (Anders 1988) 

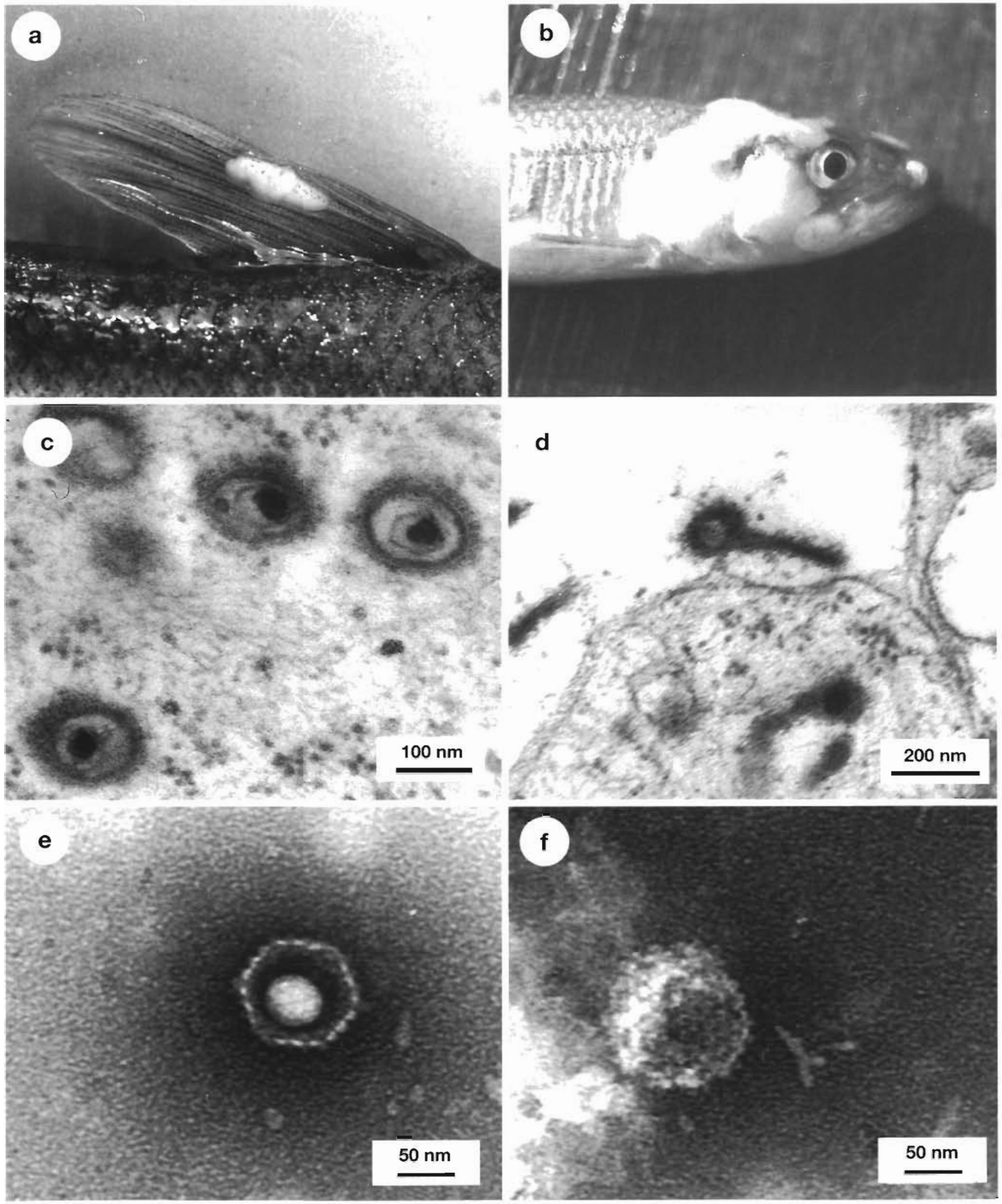

Fig. 3. Osmerus eperlanus. Epidermal papillomas in European smelt from the Elbe estuary, Germany. (a) Nodular and (b) flat epidermal hyperplasias/papillomas on fins and body surface; (c) herpesvirus particles in the cytoplasm of a tumour cell; (d) 'tailed' virus particle in cytoplasmic vacuoles of a tumour cell; (e) complete herpesvirus particles after negative staining; (f) nonenveloped particle. (From Anders 1988) 


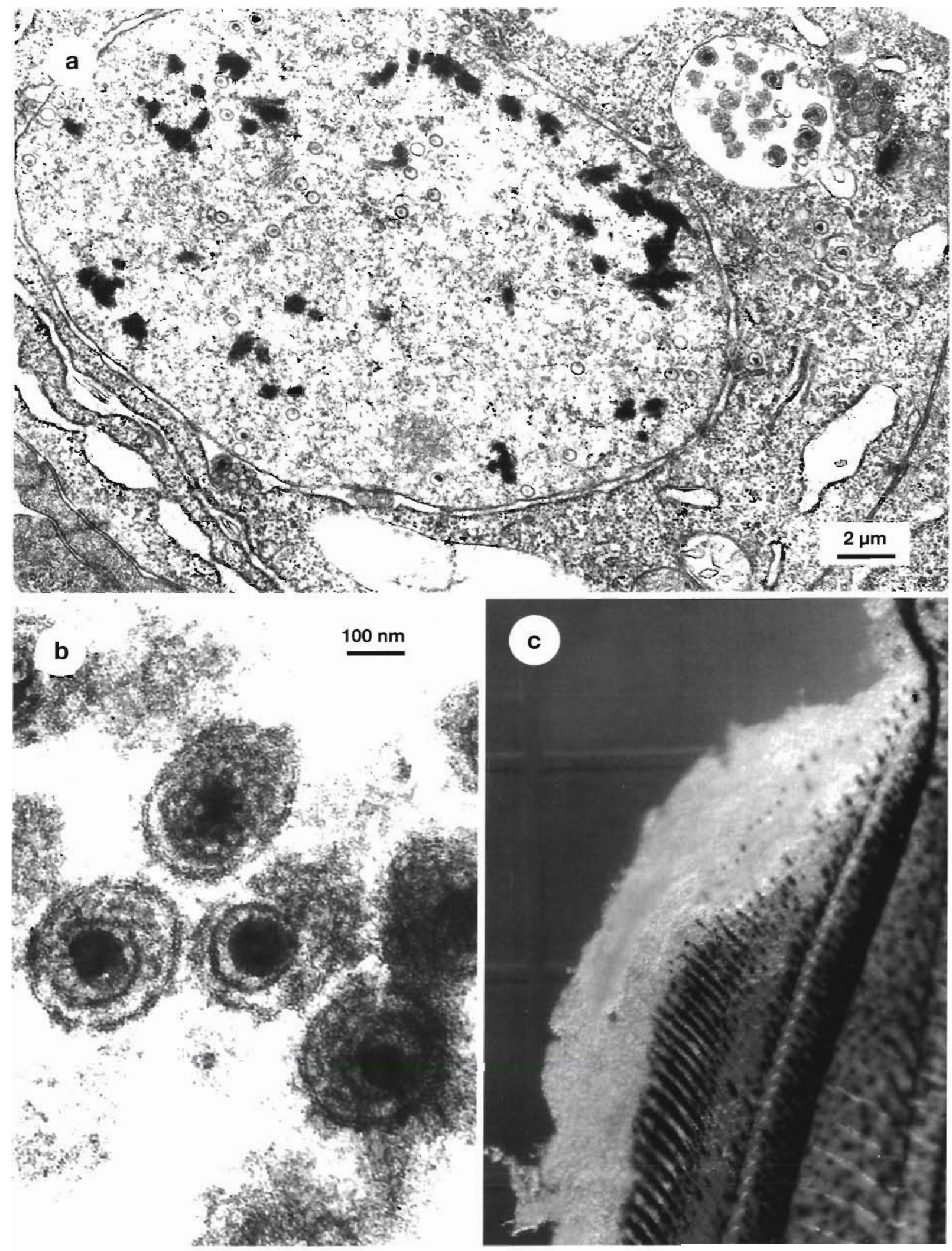

Fig 4 Paralichthys olvvaceus. Juvenule Japanese flounder from a Japanese hatchery (a) Numerous herpesvirus particles in nucleus, cytoplasm and cytoplasmic vacuoles of a hyperplastıc cell, (b) enveloped cytoplasmic virus particles; (c) typical hyperplası on the fins (Photographs a and c courtesy of Dr T. Nakai, Japan) 
The occurrence of tumours with a suspected viral etiology is well documented in a number of vertebrates including mammals, birds, reptiles (Jacobson 1981) and fish. For fish, a viral etiology of papillomas was first suggested by Keysselitz (1908). The present review summarizes and analyses current knowledge on the role of viruses in the pathogenesis of skin tumours of fish.

\section{CLASSIFICATION OF FISH SKIN TUMOURS}

Skin tumours are classified on a histopathological basis according to the origin of the proliferative cells and their degree of malignancy (Budd \& Roberts 1978). The lesions originate either from epithelial or mesenchymal cells and comprise benign as well as malignant forms, ranging from epidermal hyperplasias, epidermal papillomas and fibromas to carcinomas and sarcomas. Leukemias which may also affect the skin are not covered in this review.

Among the naturally occurring fish tumours, benign epidermal hyperplasias and papillomas are most frequently observed.

Amebic pseudotumours of several Pacific flatfish species and similar conditions of gills of dab and pseudobranchs of gadids were originally classified as epidermal papillomas until the unique ' $X$-cells' which were found to be frequently associated with the growths were identified as parasitic amebae (Dawe 1981, Shinkawa \& Yamazaki 1987).

\section{CAUSES OF FORMATION OF FISH SKIN TUMOURS}

Causes of fish tumour development are varied and often suspected to be multifactorial.

There is evidence that irritation of the skin due to constant mechanical damage or parasitic encystment may lead to the formation of tumourous growths, mostly epidermal hyperplasias (Nigrelli 1948a, Schlumberger 1953, McQueen et al. 1973, Peters \& Watermann 1979). These and other non-viral etiologies such as influences of carcinogenic chemicals and UV radiation are not covered in this review.

Due to the frequent epidemic occurrence of fish tumours, an infectious viral etiology has been suggested by many scientists, even though they could not always demonstrate visible virus particles. In these cases, evidence was usually based on the exclusion of other potential causative factors. From a detailed study of the scientific literature, it is concluded that viruses play an important role in the induction of skin tumours of fish. In about $50 \%$ of all cases where electronmicroscopical and virological methods have been ap- plied, viruses or virus-like particles were identified in tumour tissue. In benign tumours, such as epidermal hyperplasias, papillomas and fibromas, these were mostly herpesviruses, and less frequently adeno-, retro-, rhabdo-, birna- or picornaviruses (Table 1). In malignant forms like sarcomas and lymphosarcomas, there was evidence for the involvement of retroviruses only (Table 2). Typically, the tumours carried just one virus type. In rare cases, different skin tumour types associated with different viruses occurred in the same specimen (Yamamoto et al. 1985b).

The significance of these viruses and virus-like particles for tumour induction is mostly speculative. So far, only for herpesviruses isolated from benign tumours of masu salmon Oncorhynchus masou and Japanese Asagi carp Cyprinus carpio has oncogenicity been clearly demonstrated (Table 3). Although in certain other cases tumour formation could be induced experimentally by inoculation of cell-free filtrates and/or live tumour cells (Tables $3 \& 4$ ), attempts to isolate viruses in cell culture were unsuccessful.

Four categories of viruses or virus-like particles have been identified which are listed in descending order according to their degree of elucidation as causative agents. Each virus is listed only once.

\section{Viruses of proven oncogenicity}

For 2 herpesviruses, pathogenicity and oncogenicity have been clearly verified by successful isolation of the causative virus in cell culture and fulfillment of River's postulates. So far, nothing is known about possible oncogenes of these viruses.

Oncorhynchus masou virus (OMV). This agent is a salmonid herpesvirus first isolated from ovarian fluids of masu salmon in Hokkaido, Japan, in 1978 (Fig. 5b) (Kimura et al. 1981a). The virus has since been isolated frequently from mature masu salmon from Hokkaido hatcheries. OMV is pathogenic for the salmonid species masu salmon Oncorhynchus masou, chum salmon O. keta, kokanee salmon $O$. nerka, coho salmon $O$. kisutch and rainbow trout $O$. mykiss.

Affected fish become anorexic and may show exophthalmia or petechiation on the body surface. Cumulative mortality reached 80 to $100 \%$ in masu, chum and kokanee salmon ( 1 mo old), and 29 to $39 \%$ in coho salmon and rainbow trout (Kimura et al. 1983). Beginning at about 4 mo post-infection and persisting for at least $1 \mathrm{yr}, 12$ to $100 \%$ of surviving chum, coho and masu salmon and rainbow trout developed epithelial tumours around the mouth (Kimura et al. 1981b, Yoshimizu et al. 1987). The tumours were characterized as epidermal papillomas (Fig. 5a). Several layers of squamous epithelial cells in a papillomatous array 
Table 1. Naturally occurring benign fish skin tumours associated with viruses or virus-like particles (VLP). P: epidermal papilloma; $\mathrm{H}$ : epidermal hyperplasia; $\mathrm{M}$ : melanoma; $\mathrm{F}$ : fibroma; 1 to 5 : currently accepted tumour names $(1=$ 'cauliflower' tumour/stomatopapilloma, 2 = 'spawning papilloma(tosis)', 3 = walleye diffuse epidermal hyperplasia, $4=$ walleye discrele epidermal hyperplasia, 5 = walleye dermal 'sarcoma'): T: transmission electron microscopy of tumour tissue; I: isolation from tumour tissue; E: successful experimental infection; R: reisolation; Pr: activation of virus by tumour promoter. ${ }^{+}$Evidence for reverse transcriptase activity; "proven oncogenicity; syn.: synonym

\begin{tabular}{|c|c|c|c|c|}
\hline Host species & $\begin{array}{l}\text { Tumour } \\
\text { type }\end{array}$ & $\begin{array}{l}\text { Associated } \\
\text { virus or VLP }\end{array}$ & $\begin{array}{l}\text { Proof } \\
\text { by }\end{array}$ & Source \\
\hline Anguilla anguilla & $\begin{array}{l}\mathrm{P} 1 \\
\mathrm{H}\end{array}$ & $\begin{array}{l}\text { Rhabdovirus } \\
\text { Herpesvirus }\end{array}$ & $\begin{array}{l}\mathrm{I} \\
\mathrm{T}\end{array}$ & $\begin{array}{l}\text { Ahne et al. (1987) } \\
\text { Bekesi et al. (1986) }\end{array}$ \\
\hline Oncorhynchus masou & $\begin{array}{l}P \\
P\end{array}$ & $\begin{array}{l}\text { Herpesvirus } \\
\qquad \text { (OMV) } \\
\quad \text { (YTV) }^{*} \text { (syn.) } \\
\text { Rhabdovirus (IHNV) } \\
\text { Birnavirus (IPNV) }\end{array}$ & $\begin{array}{l}\text { I, E, R } \\
\text { I, E, R } \\
\text { I } \\
\text { I }\end{array}$ & $\begin{array}{l}\text { Kimura et al. (1981a, b), } \\
\text { Yoshimizu et al. (1987) } \\
\text { Sano et al. (1983) } \\
\text { Yoshimizu et al. (1989) } \\
\text { Yoshimizu et al. (1989) }\end{array}$ \\
\hline Salmo salar & $\begin{array}{l}\mathrm{H}, \mathrm{p} \\
\mathrm{P}\end{array}$ & $\begin{array}{l}\text { Retro- } Y I P \\
\text { Herpes-VLP }\end{array}$ & $\stackrel{T}{T}$ & $\begin{array}{l}\text { Carlisle (1977) } \\
\text { Shchelkunov et al. (1992) }\end{array}$ \\
\hline Salvelinus namaycush & $H(?)$ & Herpesvirus & $\mathrm{T}, \mathrm{E}$ & $\begin{array}{l}\text { McAllister \& Herman (1989), } \\
\text { Bradley et al. (1989) }\end{array}$ \\
\hline Osmerus eperlanus & $\begin{array}{l}\mathrm{H} 2 \\
\mathrm{H} \\
\mathrm{H}\end{array}$ & $\begin{array}{l}\text { Herpesvirus } \\
\text { Retro-VLP } \\
\text { Picorna-VLP }\end{array}$ & $\begin{array}{l}\mathrm{T} \\
\mathrm{T} \\
\mathrm{I}\end{array}$ & $\begin{array}{l}\text { Anders \& Möller (1985), Anders } \\
\quad \text { (1989), Lee \& Whitfield (1992) } \\
\text { Anders (1989) } \\
\text { Ahne et al. (1990) }\end{array}$ \\
\hline $\begin{array}{l}\text { Esox lucius } \\
\text { Europe } \\
\text { North America }\end{array}$ & $\begin{array}{l}\mathrm{H} \\
\mathrm{H} \\
\mathrm{H}\end{array}$ & $\begin{array}{l}\text { Herpesvirus } \\
\text { Retro-VLP } \\
\text { Retro-VLP }\end{array}$ & $\begin{array}{l}\mathrm{T} \\
\mathrm{T} \\
\mathrm{T}\end{array}$ & $\begin{array}{l}\text { Yamamoto et al. (1984) } \\
\text { Winquist et al. (1968) } \\
\text { Yamamoto el al. (1984), } \\
\text { Sonstegard (1976) }\end{array}$ \\
\hline $\begin{array}{l}\text { Cyprinus carpio } \\
\text { Asagi carp (Japan) } \\
\text { Common carp (Europe) }\end{array}$ & $\begin{array}{l}\mathrm{P} \\
\mathrm{P}\end{array}$ & $\begin{array}{l}\text { Herpesvirus (CHV) } \\
\text { Herpesvirus }\end{array}$ & $\begin{array}{l}\mathrm{T}, \mathrm{I}, \mathrm{E}, \mathrm{R} \\
\mathrm{T}\end{array}$ & $\begin{array}{l}\text { Sano et al. }(1985 a, b, 1990) \\
\text { Schubert }(1964,1966)\end{array}$ \\
\hline Leuciscus idus & $\mathrm{H}, \mathrm{P}$ & Herpesvirus & $\mathrm{T}$ & McAllister et al. (1985) \\
\hline Catostomus commersoni & $\mathrm{P}$ & Retro-VLP+ & $\mathrm{T}$ & Sonstegard $(1973,1977)$ \\
\hline Xiphophorus hybrids & M & Papova-VLP & $\mathrm{T}, \mathrm{Pr}$ & Kollinger et al. (1979) \\
\hline Ictalurus nebulosus & $\mathrm{P}$ & VLP & $\mathrm{T}$ & Edwards \& Samsonoff (1977) \\
\hline Silurus glanis & $\mathrm{H}, \mathrm{P}$ & Herpesvirus & $\mathrm{T}$ & Bekesi et al. (1981) \\
\hline Gadus morhua & $\mathrm{H}$ & Adeno-VLP & $\mathrm{T}$ & Jensen \& Bloch (1980) \\
\hline Merlangius merlangus & $\mathrm{H}$ & VLP & $\mathrm{T}$ & Anders (1988) \\
\hline Stizostedion vitreum & $\mathrm{H} 3$ & Herpesvirus & $\mathrm{T}, \mathrm{I}$ & $\begin{array}{l}\text { Kelly et al. }(1980,1983) \\
\text { Yamamoto et al. }(1985 b)\end{array}$ \\
\hline & $\mathrm{H} 4$ & Retro-VLP & $\mathrm{T}$ & $\begin{array}{l}\text { Walker }(1969 a) \text {, Yamamoto et al. } \\
\quad(1985 a, b)\end{array}$ \\
\hline & F5 & Retrovirus (foamy virus group) & $\mathrm{T}, \mathrm{R}$ & Yamamoto et al $(1976)$ \\
\hline Sparus aurata & $\mathrm{P}$ & VLP & $\mathrm{T}$ & Gutierrez et al. (1977) \\
\hline Agonus cataphractus & $F$ & Retro-VLP (lentivirus group) & $\mathrm{T}$ & Anders et al. (1991) \\
\hline Limanda limanda & $\begin{array}{l}\mathrm{H}_{1} \mathrm{P} \\
\mathrm{H}\end{array}$ & $\begin{array}{l}\text { Adeno-VLP } \\
\text { Birnavirus }\end{array}$ & $\begin{array}{l}\mathrm{T} \\
\mathrm{I}\end{array}$ & $\begin{array}{l}\text { Bloch et al. (1986) } \\
\text { Olesen et al. (1988) }\end{array}$ \\
\hline$P_{\text {seudopleuronectes americanus }}$ & $\mathrm{H}, \mathrm{P}$ & Papova(?)-VLP & $\mathrm{T}$ & Emerson et al. (1985) \\
\hline Paralichthys olivaceus & $\mathrm{H}$ & Herpesvirus & $T, E$ & $\begin{array}{l}\text { Iida et al. (1989), Masumura } \\
\text { et al. (1989), Kimura \& } \\
\text { Yoshimizu (1991b) }\end{array}$ \\
\hline
\end{tabular}

Table 2. Naturally occurring malignant fish skin tumours associated with viruses or virus-like particles (VLP). S: sarcoma; $\mathrm{L}$ : lymphosarcoma $\mathrm{T}$ : transmission electron microscopy of tumour tissue; Rt: evidence of reverse transcriptase activity

\begin{tabular}{|lcccc|}
\hline Host species & $\begin{array}{c}\text { Tumour } \\
\text { type }\end{array}$ & $\begin{array}{c}\text { Associated } \\
\text { virus or VLP }\end{array}$ & $\begin{array}{c}\text { Proof } \\
\text { by }\end{array}$ & Source \\
\hline Esox lucius & $\mathrm{S}$ & Retro-VLP & T & Winqvist et al. (1973) \\
Stizostedion vitreum & $\mathrm{L}$ & Retrovirus & Rt & Papas et al. (1976) \\
& $\mathrm{S}$ & Retro-VLP & T, Rt & Yamamoto et al. (1976) \\
\hline
\end{tabular}


Table 3. Experimentally induced benign skin tumours in fish. P: epidermal papilloma; H: epidermal hyperplasia; F: fibroma ('walleye dermal sarcoma'). 'Presumable oncogenicity, indicated by means of cell-free filtrates

\begin{tabular}{|c|c|c|c|}
\hline Host species & $\begin{array}{l}\text { Tumour } \\
\text { type }\end{array}$ & Oncogenic virus & Source \\
\hline Oncorhynchus keta & P & Herpesvirus (OMV \& YTV) & $\begin{array}{l}\text { Kimura et al. (1981a, b, 1983), Sano et } \\
\text { al. (1983), Yoshimizu et al. (1987) }\end{array}$ \\
\hline Oncorhynchus kisutch & $\mathrm{P}$ & Herpesvirus (OMV) & Yoshimizu et al. (1987) \\
\hline Oncorhynchus masou & $\mathrm{P}$ & Herpesvirus (OMV \& YTV) & Sano et al. (1983), Yoshimizu et al. (1987) \\
\hline Oncorhynchus mykiss & $\mathrm{P}$ & Herpesvirus (OMV) & Yoshimizu et al. (1987) \\
\hline Salvelinus namaycush & $\mathrm{H}$ & Herpesvirus & McAllister \& Herman (1989) \\
\hline Cyprinus carpio & $P$ & Herpesvirus & Sano et al. (1985a, b, 1990) \\
\hline Stizostedion vitreum & $\mathrm{F}$ & Retrovirus & Martineau et al. (1990), Bowser et al. (1990) \\
\hline Paralichthys olivaceus & $\mathrm{H}$ & Herpesvirus ${ }^{*}$ & lida et al. (1989), Masumura et al. (1989) \\
\hline
\end{tabular}

Table 4. Experimentally induced malignant skin tumours in fish L: lymphosarcoma; S: sarcoma; Sc: squamous cell carcinoma; N: neurofibroma. ${ }^{\mathrm{a}}$ Inoculation of cell-free filtrates, ${ }^{\mathrm{b}}$ inoculation of homogenized tumour tissue, ${ }^{c}$ inoculation of live tumour cells; " evidence for visible retrovirus in tumour tissue by electron microscopy

\begin{tabular}{|c|c|c|}
\hline Host species & $\begin{array}{l}\text { Tumour } \\
\text { type }\end{array}$ & Source \\
\hline Esox masquinongy & $L^{d}$ & Sonstegard (1976) \\
\hline Esox lucius & $\begin{array}{l}\mathrm{L}^{\mathrm{a}_{\mathrm{a}} \mathrm{c}} \\
\mathrm{S}^{c_{1}}\end{array}$ & $\begin{array}{l}\text { Sonstegard (1976), Mulcahy } \\
\text { \& O'Leary }(1970) \\
\text { Ljungberg }(1976)\end{array}$ \\
\hline $\begin{array}{l}\text { Scardinius } \\
\text { erythrophthalmus }\end{array}$ & $\mathrm{Sc}^{\mathrm{c}}$ & Hanjavanit \& Mulcahy (1989) \\
\hline Pomacentrus partitus & $N^{b}$ & Schmale \& Hensley (1988) \\
\hline
\end{tabular}

were supported by a fine connective tissue stroma. Abundant mitotic figures suggested a highly proliferative nature. Tumours appearing on the caudal fin, gill cover, body surface, corneas of the eye and kidney showed characteristics similar to those of the mouth (Yoshimizu et al. 1987). Electron microscopy revealed that the tumour cells had a typical neoplastic feature of variability in nuclear size and loose intercellular connections. However, OMV particles have never been found in either the nuclei or cytoplasm of tumour cells (Kimura et al. 1981b, Yoshimizu et al. 1987).

In 1981, Sano and co-workers (1983) isolated a virus from immature masu salmon bearing spontaneous papillomas on the jaws. They named the virus YTV (Yamame tumour virus). Comparative virological studies on both OMV and YTV revealed that they were closely related. OMV and YTV strains isolated from masu salmon were even the same (Hedrick et al. 1987, Eaton et al. 1991). Therefore, it can be concluded that YTV is a synonym for OMV due to its later description. Recently, OMV was isolated from tumour tissue of pen-cultured coho salmon and from coho salmon cultured in freshwater as well as in seawater (Kimura \& Yoshimizu 1991b).
Cyprinid herpesvirus (CHV). Schubert (1964) first visualized this virus by electron microscopy. It is associated with the earliest known skin tumour of fish, the so-called 'carp-pox' papilloma of common carp Cyprinus carpio. After several unsuccessful attempts to isolate the virus in cell culture by European virologists, it was recovered from naturally occurring papillomas of Japanese fancy carps (Sano et al. 1985a, b). The isolate was virulent for carp fry following exposure by immersion. Cumulative mortality in $2 \mathrm{wk}$ old common carp was $85.7 \%$ and in $4 \mathrm{wk}$ old fancy carp $20 \%$. The virus was reisolated from all moribund fish and all survivors. At 5 to 6 mo post-infection, $83 \%$ of surviving common and fancy carp fry developed epidermal papillomas on fins, body surface, mandibles and the sites of inoculation. Experimental infection of adult specimens led to $13 \%$ tumour incidence in mirror carp and $10 \%$ in fancy carp. In $50 \%$ of the cases, CHV was successfully reisolated from tumourous fry (Sano et al. $1985 a, b)$.

\section{Non-isolated viruses associated with successful experimental transmission}

There is strong evidence for potential oncogenicity of 2 additional herpesviruses, and possibly more than 2 retroviruses, which have not yet been isolated in cell culture but which have been associated with successful experimental transmissions of infections.

Between 1985 and 1987, several outbreaks of a disease in larval and juvenile Japanese flounder Paralichthys olivaceus were recorded in Japanese hatcheries (Iida et al. 1989). The disease occurred in 10 to $30 \mathrm{~d}$ old fish which were reared at water temperatures of 18 to $20^{\circ} \mathrm{C}$. Within a few weeks, mortalities reached 80 to $90 \%$. Affected specimens had opaque fins and a 


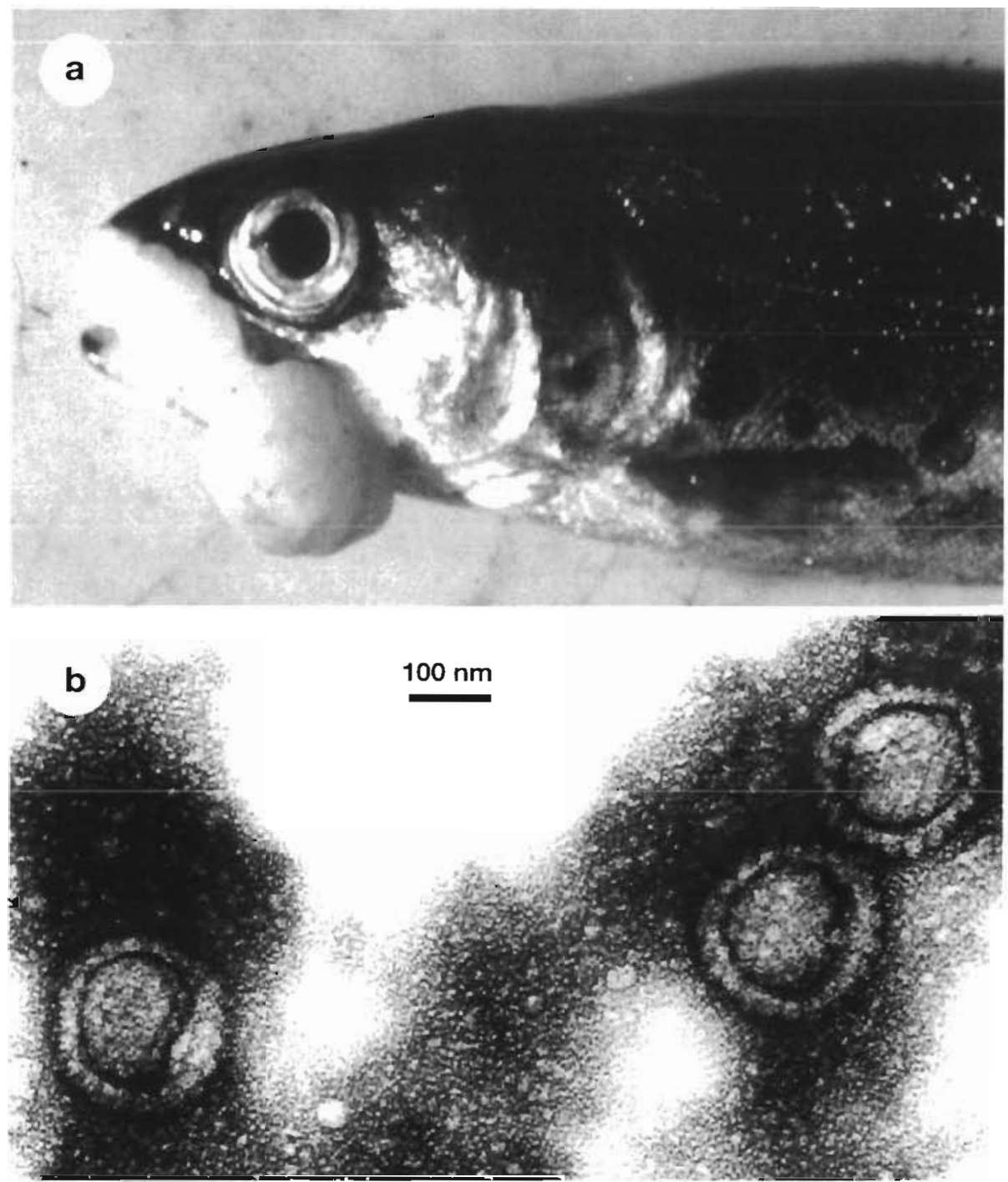

Fig. 5. Oncorhynchus masou. Papillomas in Japanese masu salmon. (a) Typical epidermal papillomas on the jaws; (b) isolated herpesvirus particles after negative staining (Kimura \& Yoshimizu 1991a) layer of proliferated epithelial cells on their fins and body surface (Fig. 4c). Electron microscopy revealed numerous hexagonal virus-like particles in both the nucleus and cytoplasm of the tumour cells (Fig. 4a, b). The condition was transmitted to healthy larval flounder by exposure to a $0.45 \mu \mathrm{m}$ filtrate of tumour tissue homogenate. The morphological features (as demonstrated by electron microscopy) and sensitivity of the agent to ether and $\mathrm{pH} 3$ indicated that it was a herpesvirus (Iida et al. 1989) but attempted isolation using 33 fish cell lines was not successful (Kimura \& Yoshimizu 1991a).

Bradley et al. (1989) and McAllister \& Herman (1989) reported on epizootic mortalities among hatcheryreared fingerling and yearling lake trout Salvelinus namaycush. Epithelial hyperplasias on jaws, the body surface or inside the mouth were consistently found associated with the disease. In both cases, a putative herpesvirus was observed in tumour tissue by electron microscopy. Experimental transmission of the infection was successful by cohabitation with diseased fish, by exposure to water from tanks holding diseased fish, and by bath challenge using cell-free filtrates of epidermal hyperplastic tissue.

Martineau et al. (1990) and Bowser et al. (1990) successfully transmitted the so-called 'dermal sarcoma' of walleye Stizostedion vitreum, which is considered benign.

It is notable that successful experimental induction of benign tumours was mostly associated with herpesviruses, whereas formation of malignant forms seems to be restricted to the involvement of retroviruses of the subfamily Oncovirinae.

It has not yet been possible to isolate a tumourassociated retrovirus in cell culture. However, in several cases experimental induction of malignant skin 
tumours using cell-free filtrates or live tumour cells was successful, thus suggesting a viral etiology (Table 4). Furthermore, several research groups are circumventing problems with cell culture by taking a molecular approach.

\section{Viruses visualized by electron microscopy}

This group includes herpesvirus, adenovirus, papovavirus and retrovirus members as well as unidentified particles of a doubtful viral nature.

Herpesviruses. To date, a total of 22 apparently distinct viruses, including OMV and CHV, have been described from cartilaginous and bony fish (Hedrick \& Sano 1989). Twelve were associated with epidermal tumours including OMV and CHV, 1 with spawning papillomatosis of smelt (Fig. $3 \mathrm{c}$ to f), 3 with so-called 'giant cell hyperplasias' (McArn et al. 1978, McCain et al. 1979, Yamamoto et al. 1984, Leibovitz \& Lebouitz 1985), and 1 with giant cell formation within a nonaltered epidermis (Buchanan \& Madeley 1978). The other 5 comprise the 2 salmonid herpesviruses Herpesvirus salmonis (Wolf \& Taylor 1975, Hedrick et al. 1986) and NeVTA (Nerka Virus in Towada Lake Akita and Aomori Prefecture: Sano 1976), a herpesvirus of European and Japanese eels (Sano et al. 1988), channel catfish virus (Fijan et al. 1970), and a recently described herpesvirus from white sturgeon (Hedrick et al. 1991). Little is known about the phylogenetic relationships of fish herpesviruses except for the rontumour-associated salmonid virus species. Close serological and genetic relationships were determined for 2 North American isolates of $H$. salmonis and 3 Japanese isolates (NeVTA and OMV), but the 2 groups differed significantly from each other (Hedrick et al. 1987, Eaton et al. 1991, Guo et al. 1991).

Adenoviruses. Adenovirus-like particles were described in Baltic cod Gadus morhua by Jensen \& Bloch (1980) and North Sea dab Limanda limanda by Bloch et al. (1986). In both cases, virus-like particles were associated with epidermal hyperplasias and pap:llomas (Fig. 2b). Neither agent could be isolated in fish cell cultures. Needham (cited by Carlisle 1975) found virus-like particles 40 to $70 \mathrm{~nm}$ in diameter in the nuclei of salmon papilloma cells by electron microscopy. These particles morphologically resembled an adenovirus.

Papovaviruses. Known to be responsible for the formation of mammalian warts (Almeida et al. 1962, Amtmann \& Sauer 1982), naturally occurring papovavirus-associated tumours in fish have not been observed so far. However, there is evidence for production of papovavirus-like particles in melanomas of Xiphophorus hybrids following treatment of tumour- bearing fish with the tumour promoter 5-bromodeoxyuridine (BrUdr) (Kollinger et al. 1979).

Retroviruses. Seventeen retroviruses and retroviruslike particles have been found in fish to date. Ten were associated with skin tumours, 1 (doubtful case) with a granuloma (Moser et al. 1986), 1 with a swimbladder fibrosarcoma in Atlantic salmon Salmo salar (Duncan 1978), and 1 within the capsular material of a lymphocystis cell (Walker 1985). Four spontaneously productive C-type retroviruses infecting 4 cell lines derived from 3 species of tropical fish represent the first in vitro cultured retroviruses of fish (Frerichs et al. 1991). It is not known whether these 4 isolates are related to any tumourous condition of fish. In 3 additional cases, the finding of tumour-associated virus-like particles remains doubtful due to insufficient ultrastructural evidence (Edwards \& Samsonoff 1977, Gutierrez et al 1977, Emerson et al. 1985).

In 2 of the virus-associated skin tumours examined histologically, retrovirus particles were classified as members of the foamy virus and the lentivirus groups; the other retroviruses could not be assigned to any of the other 5 genera of the Retroviridae family as defined recently by Francki et al. (1991). The first case is a possible member of the lentivirus group (Fig. 6a, b), representing the first report of a tumour-associated lentivirus (Anders et al. 1991, Anders \& Möller 1992) The other case is a possible member of the foamy virus group which is associated with the so-called 'walleye dermal sarcoma' (Martineau et al. 1991a, b). Reverse transcriptase activity in tissue extracts could be shown for 3 skin-tumour-associated oncoviruses from Esox Iucius (Papas et al. 1976), Catostomus commersoni (Sonstegard 1977), and Stizostedion vitreum (Martineau et al. 1991b). The latter authors found strong evidence for the involvement of a unique exogenous retrovirus which was found predominantly unintegrated in tumour cells in walleye dermal sarcoma (WDS)

\section{Viruses isolated from but not visualized in tumour tissue}

All tumour-associated rhabdovirus, birnavirus and picornavirus-like particles fall within this group.

The 2 best-studied conditions are the so-called 'cauliflower tumour' of European eel and papillomas of Japanese masu salmon. In the case of eel, Rhabdovirus anguilla, an infectious pancreatic necrosis (IPN)-like virus and an as yet unidentified agent were isolated from tumour tissue (Ahne \& Thomsen 1985, Ahne et al. 1987). Using a co-culture method, Yoshimizu and coworkers (1989) isolated OMV herpesvirus, infectious haematopoietic necrosis (IHN) rhabdovirus and IPN 

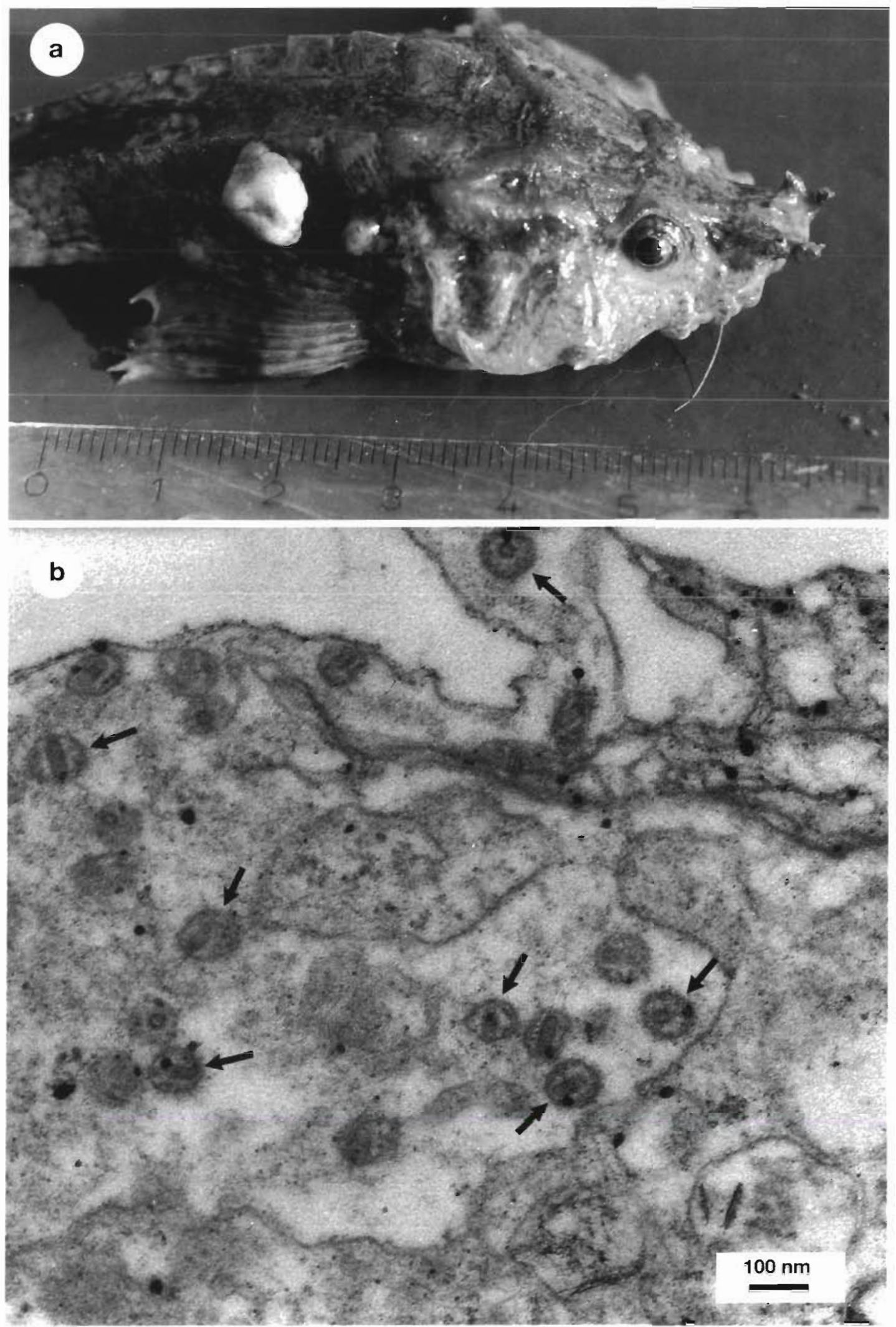

Fig. 6. Agonus cataphractus. Hooknose from the German Wadden Sea. (a) Two conspicuous fibroma-like tumours on the body surface; (b) numerous lentivirus-like particles (arrows) in the cytoplasm of a tumour cell 
birnavirus (serotype VR 299) from papilloma tissue of a naturally infected masu salmon. The recent isolation of a picorna-like virus from epidermal hyperplasias of European smelt is the first report of an association of this type of virus with fish tumours (Ahne et al. 1990). Additionally, a virus belonging to serogroup II of aquatic birnaviruses has been isolated from one of 64 dab specimens carrying epidermal hyperplasias (Olesen et al. 1988).

Experimental infection trials were unsuccessful with all isolated rhabdo- and birnaviruses. No experimental infection studies were undertaken with the picornavirus. The role of these viruses in the development of tumours therefore remains unclear. Their presence in tumour tissue is most likely to be coincidental.

\section{SEASONAL VARIATION IN TUMOUR PREVALENCE}

There is a marked seasonality in the incidence of several frequently occurring skin tumours of fish (Table 5). The highest infection rates are particularly evident during spawning periods (many species), smoltification (Atlantic salmon Salmo salar, lake trout Salvelinus namaycush), onset of differentiation of the gonads (European eel Anguilla anguilla) and meta- morphosis (Japanese flounder Paralichthys olivaceus). In all cases, these periods of maximum tumour prevalence correspond with those life stages of the affected fish where profound endocrinological changes occur in the animal, presumably affecting both condition of the skin and replication of associated viruses.

\section{PROPOSED INTERACTIONS BETWEEN THE SKIN, TUMOUR VIRUSES, BIOLOGICAL AND ENVIRONMENTAL FACTORS}

There is strong evidence that fundamental principles govern the development of skin tumours of fish within a framework of environmental parameters described in the preceeding sections of this review. Analysis of present knowledge has led to a hypothesis which is supported by extrapolation of evidence from work with different groups of fish. The hypothesis is illustrated in Fig. 7 and stated below.

First, it is considered that the formation of most, if not all, fish epidermal tumours is induced by viruses of the Herpes-, Adeno-, Papova- and Retroviridae families. It should be noted that in human oncology, representatives of the same virus families are also held responsible for induction of skin tumours (zur Hausen 1980).

Table 5. Times of the year and lifestages of host fish with maximum prevalences of skin tumours of fish. P: epidermal papilloma; H: epidermal hyperplasia; S: sarcoma; L: lymphoma; Sp: spring; Su: late summer; W: winter; -: no seasonality observed; NR: not reported; La: larvae; J: juvenile specimens; A: adult specimens, increasing prevalences were found with increasing age/length of host fish. "Virus- or VLP-associated cases

\begin{tabular}{|c|c|c|c|c|c|}
\hline Host species & $\begin{array}{l}\text { Tumour } \\
\text { type }\end{array}$ & Season & $\begin{array}{l}\text { Life } \\
\text { stage }\end{array}$ & Mortality & Source \\
\hline Anguilla anguilla & $\mathrm{P}^{\bullet}$ & $\mathrm{Su}$ & J & - & Peters $(1975,1977)$, Möller (1987) \\
\hline Salmo salar & $\mathrm{p}^{*}$ & $\mathrm{Su}$ & $\mathrm{J}$ & - & $\begin{array}{l}\text { Carlisle }(1975,1977) \text {, Bylund et al. } \\
\quad(1980) \text {, Shchelkunov et al. (1992) }\end{array}$ \\
\hline Salvelinus namaycush & $\mathrm{H}^{\bullet}$ & NR & $\mathrm{J}$ & + & $\begin{array}{l}\text { Bradley et al. (1989), McAllister \& } \\
\text { Herman (1989) }\end{array}$ \\
\hline Osmerus eperlanus & $\mathrm{H}, \mathrm{P}^{\cdot}$ & $\mathrm{Sp}$ & A & - & $\begin{array}{l}\text { Breslauer (1916), Anders \& Möller (1985), } \\
\text { Anders (1989) }\end{array}$ \\
\hline Esox lucius & $\begin{array}{l}\mathrm{H} \cdot \\
\mathrm{L}\end{array}$ & $\mathrm{Sp}$ & $\begin{array}{l}\text { A } \\
\text { A }\end{array}$ & $\bar{c}$ & $\begin{array}{l}\text { Yamamoto et al. (1984) } \\
\text { Thompson \& Hildén (1988) }\end{array}$ \\
\hline Barbus fluviatilis & $\mathrm{P}$ & $\mathrm{Sp}$ & NR & $?$ & Keysselitz (1908) \\
\hline Cyprinus carpio & $\mathrm{P}^{\cdot}$ & W, Sp? & A & $?$ & Haempel (1929), Hines et al. (1974) \\
\hline Leuciscus idus & $\mathrm{H}, \mathrm{P}^{\cdot}$ & $\mathrm{Sp}$ & NR & $?$ & McAllister et al. (1985) \\
\hline Rutilus rutilus & $\mathrm{H}, \mathrm{P}$ & $\mathrm{Sp}$ & A & ? & $\begin{array}{l}\text { Andrews \& Bucke (1982), E. T. Valtonen (pers } \\
\text { comm.) }\end{array}$ \\
\hline Catostomus commersoni & $\mathrm{P}^{*}$ & NR & A & $?$ & Sonstegard (1977) \\
\hline Ictalurus nebulosus & $P^{*}$ & NR & A & $?$ & Lucké \& Schlumberger (1941) \\
\hline Lepomis macrochirus & $\mathrm{H}, \mathrm{P}$ & $\mathrm{Sp}$ & NR & ? & Nigrelli (1948b) \\
\hline Perca flavescens & $\mathrm{H}$ & NR & A & $?$ & Walker (1969b) \\
\hline Stizostedion vitreum & $\begin{array}{l}\mathrm{H}^{*} \\
\mathrm{~S}^{*}\end{array}$ & $\begin{array}{l}\text { W, Sp } \\
\mathrm{Sp}\end{array}$ & $\begin{array}{l}\mathrm{A} \\
\mathrm{A}\end{array}$ & $?$ & $\begin{array}{l}\text { Yamamoto et al. (1985a, b) } \\
\text { Bowser et al. (1988), Bowser \& Wooster (1991) }\end{array}$ \\
\hline Paralichthys olivaceus & $H^{*}$ & NR & La, J & + & lida et al. (1989), Masumura et al. (1989) \\
\hline Limanda limanda & $\mathrm{H}, \mathrm{P} \cdot$ & $\mathrm{Sp}$ & A & ? & Wolthaus (1984) \\
\hline
\end{tabular}




\section{ENVIRONMENT}

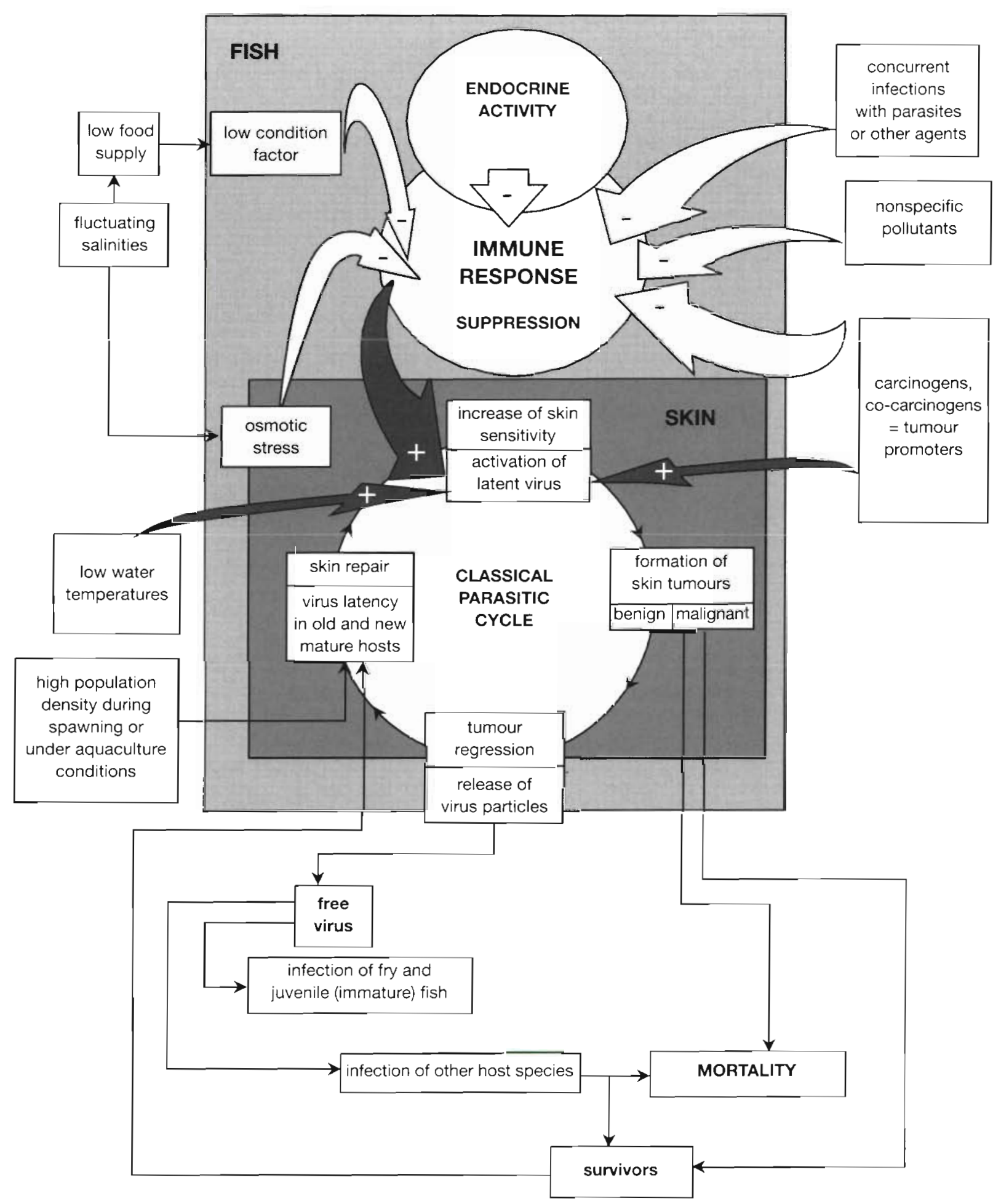

(c) M. Voigt

Fig. 7. Proposed hypothesis outlining the interactions between skin, skin tumour viruses, biological and environmental factors. (+) Stimulating factors; (-) diminishing factors 
Secondly, it is considered that the marked seasonal variation in skin tumour prevalence is a normal, expected feature of sexual maturation, spawning and metamorphosis in certain species of fish, mediated by suppression of the immune system which is itself induced by an increase in endocrinological activity. Different environmental factors may then contribute to an intensification of the process, even to the point of malignancy and subsequent death of host fish.

\section{Role of endocrine activity}

It seems likely from many epidemiological findings that the seasonal cycle of endocrine activity mediates the cyclical changes of the immune system and is the predominant factor influencing the defense mechanisms of fish. Direct evidence for this is provided by studies on the haematology of brown trout Salmo trutta which revealed significant depression of lymphocyte numbers during each of 3 separate spawning seasons (Pickering 1986) indicating a general suppression of the immune response.

It also seems likely that high levels of sex hormones in the blood of fish stimulate proliferation of the epidermis and thus act as tumour promoters in forming a sensitive substrate for the multiplication of acute and persistent infectious agents, as observed for pathogenic fungi (Richards \& Pickering 1978) and a variety of skin ectoparasites of brown trout (Pickering \& Christie 1980). An excellent review of this subject has been given by Pickering \& Richards (1980).

\section{Role of immune suppression}

Antibodies, specific agglutinins and molecules with possible antibiotic activity are almost exclusively found in skin mucus (Pickering \& Richards 1980) whereas macrophages and lymphocytes are frequent inhabitants of the epidermis (Bullock \& Roberts 1974, Roberts \& Bullock 1980).

It is widely accepted that depression of the immune response in fish favours the outbreak of infectious diseases. As the formation of skin tumours of fish is understood to be an infectious process, it may therefore be inferred that persistent tumour viruses are activated at times when the immune system is destabilized. Under normal circumstances this occurs naturally at times of spawning, smoltification and metamorphosis. Adverse environmental factors such as salinities close to the maximum tolerance level (Thompson 1982), fluctuating salinities resulting in a reduction of food supply for host fish and subsequent lowering of the condition factor (Möller 1984, 1990), high population densities on spawning grounds and high concentrations of nonspecific pollutants and carcinogens in water, sediments and food organisms may contribute to a further depression of defense mechanisms, thus enhancing prevalence rates. According to the present hypothesis, immune suppression by both natural and man-made environmental factors alone cannot stimulate expression of the tumour viruses.

\section{Viral induction of tumour formation}

The key factor of immune suppression allows activation of latent endogenous viruses. A latent infection is one in which at least the genome of the virus is present but infectious virions cannot be recovered except during episodes of overt disease (Rapp \& Jerkofsky 1973). Subsequently, virus-stimulated proliferation of epidermal and fibroblastic cells takes place leading to the formation of tumours. Additionally, carcinogenic substances and/or low water temperatures (Brown et al. 1976, Papas et al. 1976) may further enhance this process. The lesions normally regress spontaneously without leaving scars (= response of permissive cells to infection) but, in the case of malignant growths (= response of nonpermissive cells to infection, leading to a permanently transformed cell progeny), may lead to mortalities among the affected population. Lysis of benign tumour cells, especially those induced by herpesviruses, results in passive release of infective exogenous virus particles into the environment. High population densities, as may occur during spawning seasons, favour the transmission of virus particles to new host specimens. At the next stage, intracellular virus particles become dormant until they are activated once more.

The seasonal, cyclical appearance of skin tumours is valid for mature specimens only and is usually a benign process. In some cases, however, mortalities have occurred among affected adults which were mainly attributed to the formation of skin ulcerations which frequently followed spontaneous sloughing of benign skin tumours, as described for European smelt and Atlantic salmon (Carlisle \& Roberts 1977, Bylund \& al. 1980, Anders 1989). In larvae and juveniles, tumourassociated viruses can give rise to an acute systemic disease with subsequent severe mortalities as has been shown for the 4 herpesviruses OMV, Herpesvirus cyprini, herpesvirus of Japanese flounder, and Epizootic Epitheliotropic Disease virus of lake trout (Shchelkunov et al. 1992).

In the case of spawning papillomatosis of smelt, a seasonality in the occurrence of exogenous virus particles has been demonstrated by electron microscopy, with peak prevalences in the most differentiated 
tumour stages (Anders 1989). Furthermore, there was a marked increase of papilloma prevalence with increasing size of host fish, which can be explained by an increasing spread of persistent virus within the smelt population with successive cycles of virus activation and release.

\section{Are fish tumour viruses 'perfect parasites'?}

The cyclic process described above most closely resembles a classical parasitic life cycle which is commonly characterized by a free-living stage and a change of host species in some cases. As yet, it is not known whether tumour-associated viruses of fish are infective for more than 1 species or whether other aquatic organisms can serve as transmitters.

A non-tumour-associated calicivirus is the only known example of successful expression in different hosts, occurring in both marine fish and marine mammals (Smith et al. 1986, Barlough et al. 1988). Although this finding may seem surprising at first glance, it is likely to be explained by the phylogenetic position of the host system. Assuming a close co-evolution of tumour viruses and hosts through vertical transmission (Farley 1981), the naive status of their relationship may well reflect the relative simplicity of the fish host's physiology. Examples for a co-evolution of fish viruses and their host species have been summarized by Anders \& Darai (1985). It is tempting to speculate that tumour-associated viruses at the piscine level may be considered true parasites and that as the phylogenetic level of the host rises, so the 'life cycle' of associated tumour viruses becomes more specialized, culminating in the perfect endosymbiotic integration of viral genomes in the genetic substance of mammalian host cells.

\section{Malignant tumour development}

It can be further concluded from our hypothesis that carcinogenic substances in water, sediment or biota may affect the development of a benign tumour by mutational modification of cellular functions, resulting in a progress to malignancy.

\section{CONCLUDING REMARKS}

In summary, presently available evidence supports a key role for viruses in the induction of skin tumours of fish. It is concluded that other biological and environmental factors mediate either expression of the tumour virus, tumour development or both.
Overall, there are 2 broad fields for the potential application of these findings.

One area is the investigation and monitoring of environmental effects of contaminants in aquatic ecosystems, although the incidence of benign skin tumours of fish is often argued not to be an ideal indicator parameter in this respect. Unless experimental designs allow distinctions between the effects of the different biological and environmental factors influencing the immune status, the technical problems in 'detecting even a fractional increase (or decrease) in tumour incidence, which may be related to exogenous carcinogens, are enormous, and in many cases impossible to overcome' (Mix 1986). However, according to our hypothesis, and assuming that all but the 'pollution parameters' do not vary more than normal, it should be possible to detect differences in prevalence rates evidently attributable to changes in pollution levels. If so, 'biomarkers' for the presence of carcinogens in the marine environment, such as activation of cellular oncogenes and oxyradicals, could prove to be successful tools for future effect monitoring programmes.

Secondly, tumour diseases of fish may provide a sensitive animal system for exploring man-made and natural environmental factors in oncogenesis. Furthermore, studies of tumours in poikilotherms might play a unique role in developing new model systems for elucidating basic mechanisms underlying neoplastic processes. Such systems could be of value for human cancer research and offer excellent opportunities for collaborative research between fisheries ecologists and specialists in human oncology.

Acknowledgements. We are grateful to Prof. Dr Heino Möller (formerly Kiel, now Mactan, Philippines), Dr Nicolas Frerichs (Stirling) and Dr Angela Köhler-Günther (Hamburg) for critically reviewing the manuscript. Thanks are also due to Dr Matthias Voigt (Kiel) for computer graphics. This work was made possible by grants from the German Research Foundation and the German Federal Agency for the Environment (FKZ 10204 373/1).

\section{LITERATURE CITED}

Ahne, W., Anders, K., Halder, M., Yoshimizu, M. (1990). Isolation of picornavirus-like particles from the European smelt (Osmerus eperlanus). J. Fish Dis. 13: 167-168

Ahne, W., Schwanz-Pfitzner, I., Thomsen, I. (1987). Serological identification of 9 viral isolates from European eels (Anguilla anguilla) with stomatopapilloma by means of neutralization tests. J. appl. Ichthyol. 3: 30-32

Ahne, W., Thomsen, I. (1985). The existence of three different viral agents in a tumour bearing European eel (Anguilla anguilla) ZentralbI. VetMed. B32: 228-235

Almeida, J. D., Howatson, A. F., Williams, M. G. (1962) Electron microscope study of human warts; sites of virus production and nature of the inclusion bodies. J. invest. Dermatol. 38: 337-345 
Amtmann, E., Sauer, G. (1982). Activation of non-expressed bovine papilloma virus genomes by tumour promoters. Nature 296: 675-677

Anders, K. (1988). Biology of tumour- and tumour-like diseases of fish from the lower Elbe River. Möller Publications, Kiel (in German)

Anders, K. (1989). A herpesvirus associated with an epizootic epidermal papillomatosis in European smelt (Osmerus eperlanus). In: Ahne, W., Kurstak, E. (eds.) Viruses of lower vertebrates. Springer, Berlin, p. 184-197

Anders, K., Darai, G. (1985). Genome analysis of fish lymphocystis disease virus. In: Ellis, A. E. (ed.) Fish and shellfish pathology. Academic Press, London, p. 301-306

Anders, K., Hilger, I., Möller, H. (1991). Lentivirus-like particles in connective tissue tumours of fish from German coastal waters. Dis. aquat. Org. 11: 151-154

Anders, K., Möller, H. (1985). Spawning papillomatosis of smelt, Osmerus eperlanus L., from the Elbe estuary. J. Fish Dis. 8: 233-235

Anders, K., Möller, H. (1992). Atlas der Fischkrankheiten im Wattenmeer/Atlas of Fish Diseases in the Wadden Sea. Erich Schmidt, Berlin

Andrews, C., Bucke, D. (1982). Epidermal hyperplasia in a coarse fish population. Bull. Eur. Ass. Fish Pathol. 2: 29-31

Anonymous (1984). Fish cancer epidemics oversight. Hearing before subcommittees of the Committee on Merchant Marine and Fisheries, Serial No. 98-40. U.S. Government Printing Office, Washington, DC, p. 1-115

Barlough, J. E., Berry, E. S., Skilling, D. E., Smith, A. W. (1988). Prevalence and distribution of serum neutralizing antibodies to San Miguel sea lion virus types 6 and 7 in selected populations of marine mammals. Dis. aquat. Org. 5: $75-80$

Bekesi, L., Horvath, I., Kovacs-Gayer, E., Csaba, G. (1986). Demonstration of herpesvirus-like particles in skin lesions of European eel (Anguilla anguilla). J. appl. Ichthyol. 2: 190-192

Bekesi, L., Kovacs-Gayer, E., Ratz, F., Turkovics, O. (1981). Skin infection of the sheatfish (Silurus glanis L.) caused by a herpes virus. In: Olah, J., Molnar, K., Jeney, Z. (eds.) Fish, pathogens, and environment in European polyculture. Fisheries Research Institute, Szarvas, p. 59-69

Bell, W. (1793). Description of a species of Chaetodon called by the malays Eccan bonna. Phil. Trans. R. Soc. Lond. 83: $7-9$

Bloch, B., Mellergaard, S., Nielsen, E. (1986). Adenovirus-like particles associated with epithelial hyperplasias in dab, Limanda limanda (L.). J. Fish Dis, 9: 281-285

Bowser, P. R., Martineau, D., Wooster, G. A. $\{1990\}$. Effects of water temperature on experimental transmission of dermal sarcoma in fingerling walleyes (Stizostedion vitreum). J. aquat. Anim. Health 2: 157-161

Bowser, P. R., Wolfe, M. J., Forney, J. L., Wooster, G. A. (1988). Seasonal prevalence of skin tumors from walleye (Stizostedion vitreum) from Oneida Lake, New York. J. Wildl. Dis. 24: 292-298

Bowser, P. R., Wooster, G. A. (1991). Regression of dermal sarcoma in adult walleyes (Stizostedion vitreum). J. aquat. Anim. Health 3: 147-150

Bradley, T. M., Medina, D. J., Chang, P. W., McClain, J. (1989). Epizootic epitheliotropic disease of lake trout (Salvelinus namaycush): history and viral etiology. Dis. aquat. Org. 7 : 195-201

Breslauer, T. (1916). Zur Kenntnis der Epidermoidalgeschwülste von Kaltblütern. Histologische Veränderungen des Integuments und der Mundschleimhaut beim Stint (Osmerus eperlanus L.). Arch. mikrosk. Anat. 87: 200-263
Brown, E. R., Dolowy, W. C., Sinclair, T., Keith, L., Greenberg, S., Hazdra, J. J., Beamer, P., Callaghan, O. (1976). Enhancement of lymphosarcoma transmission in Esox lucius and its epidemiologic relationship to pollution. Bibl. Haemat. 43: 245-251

Buchanan, J. S., Madeley, C. R. (1978). Studies on Herpesvirus scophthalmi infection of turbot Scophthalmus maximus (L.): ultrastructural research. J. Fish Dis. 1. 283-295

Budd, J., Roberts, R. J. (1978). Neoplasia of teleosts. In: Roberts, R. J. (ed.) Fish pathology. Bailliere Tindall, London, p. 105-113

Bullock, A. M., Roberts, R. J. (1974). The dermatology of marine teleost fish. 1. The normal integument. Oceanogr. mar. Biol. A. Rev, 13: 383-411

Bylund, G., Valtonen, E. T., Niemelä, E. (1980). Observations on epidermal papillomata in wild and cultured Atlantic salmon Salmo salar L. in Finland. J. Fish Dis. 3: 525-528

Carlisle, J. C. (1975). An epidermal papilloma of the Atlantic salmon (Salmo salar). A study of its epizootiology, pathology, and immunology. M.Sc. thesis, University of Stirling, Stirling

Carlisle, J. C. (1977). An epidermal papilloma of the Atlantic salmon II: Ultrastructure and etiology. J. Wildl. Dis. 13: 235-239

Carlisle, J. C., Roberts, R. J (1977). An epidermal papilloma of the Atlantic salmon I: Epizootiology, pathology and immunology. J. Wildl. Dis. 13: 230-234

Couch, J. A., Harshbarger, J. C. (1985). Effects of carcinogenic agents on aquatic animals: an environmental and experimental overview. Environ. Carcinogenesis Revs. 3: 63-105

Dawe, C. J. (1981). Polyoma tumors in mice and X cell tumors in fish, viewed through telescope and microscope. In: Dawe, C. J., Harshbarger, J. C., Kondo, S., Sugimura, T., Takayama, S. (eds.) Phyletic approaches to cancer. Japanese Scientific Society Press, Tokyo, p. 19-49

Dawe, C. J., Harshbarger, J. C. (1975). Neoplasms in feral fishes: their significance to cancer research. In: Ribelin, W. E., Migaki, G. (eds.) The pathology of fishes. University of Wisconsin Press, Madison, p. 871-894

Dethlefsen, V. (1990). Ten years fish disease studies of the Institut für Küsten- und Binnenfischerei. Arch. Fischereiwiss. 40: 119-132

Duncan, I. B. (1978). Evidence of an oncovirus in swimbladder fibrosarcoma of Atlantic salmon Salmo salar L. J. Fish Dis. 1. $127-131$

Eaton, W. D., Wingfield, W. H., Hedrick, R. P. (1991). Comparison of the DNA homologies of five salmonid herpesviruses. Fish Pathol. 26: 183-188

Edwards, M. R., Samsonoff, W. A. (1977). Electron microscopic observations on virus-like particles of a catfish papilloma. Proc. A. Meet. electron micr. Soc. Am. 35: 394-395

Emerson, C. J., Payne, J. F., Bal, A. K. (1985). Evidence for the presence of a viral non-lymphocystis type disease in winter flounder, Pseudopleuronectes americanus (Walbauml, from the north-west Atlantic. J. Fish Dis. 8: 91-102

Farley, C. A. (1981). Phylogenetic relationships between viruses, marine invertebrates and neoplasia. In: Dawe, C. J., Harshbarger, J. C., Kondo, S., Sugimura, T., Takayama, S. (eds.) Phyletic approaches to cancer Japanese Scientific Society Press, Tokyo, p. 75-87

Fijan, N. N., Wellborne, T. L. Jr, Naftel, J. P. (1970). An acute viral disease of channel catfish. U.S. Sport Fisheries and Wildlife Tech. Pap. No. 43

Francki, R. I. B., Fauquet, C. M., Knudson, D. L., Brown, F. (eds.) (1991). Classification and nomenclature of viruses. 
Fifth report of the International Committee on Taxonomy of Viruses. Springer, Vienna

Frerichs, G. N., Morgan, D., Hart, D., Skerrow, C., Roberts, R. J., Onions, D. E. (1991). Spontaneously productive C-type retrovirus infection of fish cell lines. J. gen. Virol. 72: $2537-2539$

Guo, D. F., Kodama, H., Onuma, M., Kimura, T., Yoshimizu, M. (1991). Comparison of different Oncorhynchus masou virus (OMV) strains by DNA restriction endonuclease cleavage analysis. Jpn. J. vet. Res. 39: 27-37

Gutierrez, M., Perez Crespo, J., Arias, A. (1977). Particulas virus-like en un tumor en boca de dorada, Sparus aurata L. Invest. pesq. 41:331-336

Haempel, O. (1929). Die Pockenkrankheit des Karpfens Oesterr. FischZtg 26: 34-36, 55-56

Hanjavanit, C., Mulcahy, M. F. (1989). Squamous cell carcinoma in rudd (Pisces, Cyprinidae). In: Barja, J. L., Toranzo, A. E. (eds.) Abstracts of the IVth International Conference of the EAFP. European Association of Fish Pathologists, Santiago de Compostela, Spain, p. 89

Harshbarger, J. C. (1977). Role of the registry of tumors in lower animals in the study of environmental carcinogenesis in aquatic animals. Ann. N.Y. Acad. Sci. 298 $280-289$

Harshbarger, J. C. (1984). Pseudoneoplasms in ectothermic animals. Natl Cancer Inst. Monogr. 65: 251-273

Harshbarger, J. C., Charles, A. M., Spero, P. M. (1981). Collection and analysis of neoplasms in sub-homeothermic animals from a phyletic point of view In Dawe, C. J., Harshbarger, J. C., Kondo, S., Sugimura, T., Takayama, S. (eds.) Phyletic approaches to cancer. Japanese Scientific Society Press, Tokyo, p. 357-384

Hedrick, R. P., McDowell, T., Eaton, W. D., Chan, L. Wingfield, W. (1986). Herpesvirus salmonis (HPV): first occurrence in anadromous salmonids. Bull. Eur. Ass. Fish Pathol. 6: 66-67

Hedrick, R. P., McDowell, T., Eaton, W. D., Kimura, T., Sano, T. (1987). Serological relationships of five herpesviruses isolated from salmonid fishes. J. appl. Ichthyol. 3: 87-92

Hedrick, R. P., McDowell, T. S., Groff, J. M., Yun, S., Wingfield, W. H. (1991). Isolation of an epitheliotropic herpesvirus from white sturgeon Acipenser transmontanus. Dis. aquat. Org. 11:49-56

Hedrick, R. P., Sano, T. (1989). Herpesviruses of fishes. In Ahne, W. Kurstak, E. (eds.) Viruses of lower vertebrates. Springer, Berlin, p. 161-170

Hines, R. S., Wohlfarth, G. W., Moav, R., Hulata, G. (1974). Genetic differences in susceptibility to two diseases among strains of the common carp. Aquaculture 3: 187-197

Iida, Y., Masumura, K., Nakai, T., Sorimachi, M., Matsuda, H. (1989). A viral disease in larvae and juveniles of the Japanese flounder Paralichthys olivaceus. J. aquat. Anim. Health 1: 7-12

Jacobson, E. R. (1981). Virus associated neoplasms of reptiles In: Dawe, C. J., Harshbarger, J. C., Kondo, S., Sugimura, T., Takayama, S. (eds.) Phyletic approaches to cancer. Japanese Scientific Society Press, Tokyo, p. 53-58

Jensen, N. J., Bloch, B. (1980). Adenovirus-like particles associated with epidermal hyperplasia in cod (Gadus morhua). Nord. VetMed. 32: 173-175

Kelly, R. K., Nielsen, O., Mitchell, S. C., Yamamoto, T. (1983). Characterization of Herpesvirus vitreum isolated from hyperplastic epidermal tissue of walleye, Stizostedion vitreum vitreum (Mitchill). J. Fish Dis. 6: 249-260

Kelly, R. K., Nielsen, O, Yamamoto, T. (1980). A new herpeslike virus (HLV) of fish (Stizostedion vitreum vitreum). In Vitro 16: 255
Keysselitz, G. (1908). Ubber ein Epithelioma der Barben. Arch. Protistenkd. 11: 326-333

Kimura, T., Suzuki, S., Yoshimizu, M. (1983). In vivo antiviral effect of 9-(2-hydroxyethoxymethyl)guanine on experimental infection of chum salmon (Oncorhynchus keta) fry with Oncorhynchus masou virus (OMV). Antivir. Res. 3: $103-108$

Kimura, T., Yoshimizu, M. (1991a). Viral diseases of fish in Japan. A. Rev. Fish Dis. 1:67-82

Kimura, T., Yoshimizu, M. (1991b). Herpesviruses of salmonid fish in Japan. In: Fryer, J. L. (ed.) Proc. Second Int. Symp. Viruses of Lower Vertebrates, 29-31 July 1991. Oregon State University, Corvallis, 183-189

Kimura, T., Yoshimizu, M., Tanaka, M. (1981a). Studies on a new virus (OMV) from Oncorhynchus masou. II. Oncogenic nature. Fish Pathol. 15: 149-153

Kimura, T., Yoshimizu, M. Tanaka, M. (1981b). Fish viruses: tumor induction in Oncorhynchus keta by the herpesvirus. In: Dawe, C. J., Harshbarger, J. C., Kondo, S., Sugimura, T. Takayama, S. (eds.) Phyletic approaches to cancer. Japanese Scientific Society Press, Tokyo, p. 59-68

Kollinger, G., Schwab, M., Anders, F. (1979). Virus-like particles induced by bromodeoxyuridine in melanoma and neuroblastoma of Xiphophorus. J. Cancer Res. clin. Oncol. 95: $239-246$

Lee, S., Whitfield, P. J. (1992). Virus-associated spawning papillomatosis in smelt, Osmerus eperlanus L, in the River Thames. J. Fish Biol. 40: 503-510

Leibovitz, L., Lebouitz, S. S. (1985). A viral dermatitis of the smooth dogfish, Mustelus canis (Mitchill). J. Fish Dis. 8 $273-279$

Ljungberg, O. (1976). Epizootiological and experimental studies of skin tumours in northern pike (Esox lucius L.) in the Baltic Sea. Prog. exp. Tumor Res. 20: 156-165

Lucké, B., Schlumberger, H. G. (1941). Transplantable epitheliomas of the lip and mouth of catfish. 1. Pathology. Transplantation to anterior chamber of eye and into cornea. J. exp. Med. 74: 397-408

Martineau, D., Bowser, P. R., Armstrong, G. A., Wooster, G. A. (1990). Experimental transmission of a dermal sarcoma in fingerling walleyes (Stizostedion vitreum vitreum). Vet. Pathol. 27: 230-234

Martineau, D., Bowser, P. R., Renshaw, R. R., Casey, J. W. (1991a). Molecular characterization of a unique retrovirus associated with a fish tumor. J. Virol. 66: 596-599

Martineau, D., Renshaw, R., Williams, J. R., Casey, J, W., Bowser, P. R. (1991b). A large unintegrated retrovirus DNA species present in a dermal tumor of walleye Stizostedion vitreum. Dis. aquat. Org. 10: 153-158

Masumura, K., Iida, Y., Nakai, T., Mekuchi, T. (1989). The effects of water temperature and fish age on a herpesvirus infection of Japanese flounder larvae, Paralichthys olivaceus. Fish Pathol. 24: 111-114

Mawdesley-Thomas, L. E. (1975). Neoplasia in fish. In: Ribelin, W. E., Migaki, G. (eds.) The pathology of fishes. University of Wisconsin Press, Madison, p. 343-361

McAllister, P. E., Herman, R. L. (1989). Epizootic mortality in hatchery-reared lake trout Salvelinus namaycush caused by a putative virus possibly of the herpesvirus group. Dis. aquat. Org. 6: 113-119

McAllister, P. E., Lidgerding, B. C., Herman, R. L., Hoyer, L. C., Hankins, J. (1985). Viral diseases of fish: first report of carp pox in golden ide (Leuciscus idus) in North America. J. Wildl. Dis. 21: 199-204

McArn, G. E., McCain, B., Wellings, S. R. (1978). Skin lesions and associated virus in Pacific cod (Gadus macrocephalus) in the Bering Sea. Fed. Proc. Fed. Am. Soc. exp. Biol. 37 : 937 
McCain, B. B., Gronlund, W. D., Myers, M. S., Wellings, S. R. (1979). Tumours and microbial diseases of marine fishes in Alaskan waters. J. Fish Dis. 2: 111-130

McQueen, A., MacKenzie, K., Roberts, R. J., Young, H. (1973). Studies on the skin of plaice (Pleuronectes platessa L.). III. The effect of temperature on the inflammatory response to the metacercariae of Cryptocotyle lingua (Creplin, 1825) (Digenea: Heterophyidae). J. Fish Biol. 5: 241-247

Mix, M. C. (1986). Cancerous diseases in aquatic animals and their association with environmental pollutants: a critical literature review. Mar. environ. Res. 20: 1-141

Möller, H. (1979). Geographical distribution of fish diseases in the NE Atlantic: a bibliographic review. Meeresforschung 27: $217-235$

Moller, H. (1984). Dynamics of fish diseases in the lower Elbe River. Helgoländer Meeresunters. 37: 389-413

Möller, H. (1987). Fischbestände und Fischkrankheiten in der Unterelbe. Möller Publications, Kiel

Möller, H. (1990). Association between diseases of flounder (Platichthys flesus) and environmental conditions in the Elbe estuary, FRG. J. Cons. int. Explor. Mer 46: 187-199

Möller, H., Anders, K. (1986). Diseases and parasites of marine fishes. Möller Publications, Kiel

Möller, H., Anders, K. (1992). Epidemiology of fish diseases in the Wadden Sea. ICES J. mar. Sci. 49: 199-208

Moser, M., Jensen, L. A., Heckmann, R. A. (1986). Lesion on sablefish (Anoplopoma fimbria) of possible viral and bacterial origin. Trans. Am. Microsc. Soc. 105: $185-186$

Mulcahy, M. F., O'Leary, A. (1970). Cell-free transmission of lymphosarcoma in northern pike Esox lucius L. (Pisces; Esocidae). Experientia 26: 891

Nigrelli, R. F. (1948a). Prickle cell hyperplasia in the snout of the redhorse sucker (Moxostoma aureolum) associated with an infection by the myxosporidian Myxobolus moxostomi sp. nov. Zoologica 33: 43-46

Nigrelli, R. F. (1948b). Hyperplastic epidermal disease in the bluegill sunfish, Lepomis macrochirus Rafinesque. Zoologica 33: 133-137

Olesen, N. J., Joergensen, P. E. V., Bloch, B., Mellergaard, S. (1988). Isolation of an IPN-like virus belonging to the serogroup II of the aquatic birnaviruses from dab, Limanda limanda L. J. Fish Dis. 11: 449-451

Papas, T. S., Dahlberg, J. E., Sonstegard, R. A. (1976). Type C virus in lymphosarcoma in northern pike (Esox lucius). Nature 261: 506-508

Peters, G. (1975). Seasonal fluctuations in the incidence of epidermal papillomas of the European eel Anguilla anguilla L. J. Fish Biol. 7: 415-422

Peters, G. (1977). The papillomatosis of the European eel (Anguilla anguilla L.): analysis of seasonal fluctuations in the tumor incidence. Arch. FischWiss. 27: 251-263

Peters, N., Watermann, B. (1979). Three types of skin papillomas of flatfishes and their causes. Mar. Ecol. Prog. Ser. 1: 269-276

Pickering, A. D. (1986). Changes in blood cell composition of the brown trout, Salmo trutta L, during the spawning season. J. Fish Biol. 29: 335-347

Pickering, A. D., Christie, P. (1980). Sexual differences in the incidence and severity of ectoparasitic infestation of the brown trout, Salmo trutta L. J. Fish Biol. 16: 669-683

Pickering, A. D., Richards, R. H. (1980). Factors influencing the structure, function and biota of salmonid epidermis. Proc. R. Soc. Edinburgh 79B: 93-104

Plehn, M. (1910). Über Geschwülste bei niederen Wirbeltieren. Conf. int. Cancer (Paris), p. 221-242

Rapp, F., Jerkotsky, M. A. (1973). Persistent and latent infec- tions. In: Kaplan, A. S. (ed.) The herpesviruses. Academic Press, New York, p. 271-289

Richards, R. H., Pickering, A. D. (1978). Frequency and distribution patterns of Saprolegnia infection in wild and hatchery-reared brown trout Salmo trutta L. and char Salvelinus alpinus (L.). J. Fish Dis. 1: 69-82

Roberts, R. J., Bullock, A. M. (1980). The skin surface ecosystem of teleost fishes. Proc. R. Soc. Edinburgh 79B: 87-91

Sano, M., Fukuda, H., Sano, T (1988). Isolation and characterization of a new herpesvirus from eel. In: Perkins, F. O. Cheng, T. C. (eds.) Pathology in marine science. Academic Press, San Diego, p. 15-31

Sano, T. (1976). Viral diseases of cultured fishes in Japan. Fish Pathol. 10: 221-226

Sano, T., Fukuda, H., Furukawa, M. (1985a). Herpesvirus cyprini: biological and oncogenic properties. Fish Pathol. 20: $381-388$

Sano, T., Fukuda, H., Furukawa, M., Hosoya, H., Moriya, Y. (1985b). A herpesvirus isolated from carp papilloma in Japan. In: Ellis, A. E. (ed.) Fish and shellfish pathology. Academic Press, London, p. 307-311

Sano, T., Fukuda, H., Okamoto, N., Kaneko, F. (1983). Yamame tumor virus: lethality and oncogenicity. Bull. Jap. Soc. scient. Fish. 49: 1159-1163

Sano, T., Morita, N., Shima, N., Akimoto, M. (1990). A preliminary report on pathogenicity and oncogenicity of cyprinid herpesvirus. Bull. Eur. Ass. Fish Pathol. 10: 11-13

Schlumberger, H. G. (1953). Comparative pathology of oral neoplasms. Oral Surg 6: 1078-1094

Schlumberger, H. G., Lucké, B. (1948). Tumors of fishes, amphibians, and reptiles. Cancer Res. 8: 657-754

Schmale, M. C., Hensley, G. T. (1988). Transmissibility of a neurofibromatosis-like disease in bicolor damselfish. Cancer Res. 48: 3828-3833

Schubert, G. (1964). Elektronenmikroskopische Untersuchungen zur Pockenkrankheit des Karpfens. Z. Naturforsch. 19b: $675-682$

Schubert, G. (1966). The infective agent in carp pox. Bull. Off. int. Epiz. 65: 1011-1022

Shchelkunov, I. S., Karaseva, T. A., Kadoshnikov, Y U. P. (1992). Atlantic salmon papillomatosis: visualization of herpesvirus-like particles in skin growths of affected fish. Bull. Eur. Ass. Fish Pathol. 12: 28-31

Shinkawa, T., Yamazaki, F. (1987). Proliferative patterns of $\mathrm{X}$-cells found in the tumorous lesions of Japanese goby. Nippon Suisan Gakk. 53: 563-568

Smith, A. W., Skilling, D. E., Barlough, J. E., Berry, E, S. (1986). Distribution in the North Pacific Ocean, Bering Sea, and Arctic Ocean of animal populations known to carry pathogenic caliciviruses. Dis, aquat. Org. 2: 73-80

Sonstegard, R. A. (1973). Relationship between environmental factors and viruses in the induction of tumours in fish. In: Mahdy, M. S., Dutka, B. J. (eds.) Proc. Symp. 'Viruses in the Environment and their Potential Hazards', Burlington, Ontario, p. 119-129

Sonstegard, R. A. (1976). Studies of the etiology and epizootiology of lymphosarcoma in Esox (Esox lucius L. and Esox masquinongy). Prog. exp. Tumor Res. 20: 141-155

Sonstegard, R. A. (1977). Environmental carcinogenesis studies in fishes of the Great Lakes of North America. Ann. N.Y. Acad. Sci. 298: 261-269

Thomas, L. (1931). Les tumeurs des poissons. (Etude anatomique et pathogénique.) Bull. Ass. Fr. Etude Cancer 20: $703-760$

Thompson, J. S. (1982). An epizootic of lymphoma in northern pike, Esox lucius L., from the Aland Islands of Finland. J. Fish Dis. 5: 1-11 
Thompson, J. S., Hildén, M. (1988). Population characteristics of true histiocytic lymphoma in northern pike, Esox lucius L., from the Aland Islands of the Baltic Sea. Aqua Fennica 18: $85-92$

Walker, R. (1969a). Virus associated with epidermal hyperplasia in fish. Natl Cancer Inst. Monogr. 31: 195-207

Walker, R. (1969b). Epidermal hyperplasia in fish: two types without visible virus. Natl Cancer Inst. Monogr. 31: $209-213$

Walker, R. (1985). Lymphocystis cells infected with retroviruslike particles. Fish Health News 14 : iii-V

Winqvist, G., Ljungberg, O., Hellstroem, B. (1968j. Skin tumours of northern pike (Esox lucius L.) II. Viral particles in epidermal proliferations. Bull. Off. int. Epiz. 69: 1023-1031

Winqvist, G., Ljungberg, O., Ivarsson, B. (1973). Electron microscopy of sarcoma of the northern pike (Esox lucius L.). In: Dutcher, R. M., Chieco-Bianchi, L. (eds.) Unifying concepts of leukemia. Bibl. haemat. No. 39. Karger, Basel, p. $26-30$

Wolf, K., Taylor, W. G. (1975). Salmonid viruses: a syncytiumforming agent from rainbow trout. Fish Health News 4: 3

Wolthaus, B. G. (1984). Seasonal changes in frequency of diseases in dab, Limanda limanda, from the southern North Sea. Helgoländer Meeresunters. 37: 375-387

Yamamoto, T., Kelly, R. K., Nielsen, O. (1984). Epidermal

Responsible Subject Editor: F. M. Hetrick, College Park, Maryland, USA hyperplasias of northern pike (Esox lucius) associated with herpesvirus and C-type particles. Archs Virol. 79 $255-272$

Yamamoto, T., Kelly, R. K., Nielsen, O.(1985a). Epidermal hyperplasia of walleye, Stizostedion vitreum vitreum (Mitchill), associated with retrovirus-like type-C particles prevalence, histologic and electron microscopic observations. J. Fish Dis. 8: 425-436

Yamamoto, T., Kelly, R. K., Nielsen, O. (1985b). Morphological differentiation of virus-associated skin tumors of walleye (Stizostedion vitreum vitreum). Fish Pathol. 20: 361-372

Yamamoto, T., MacDonald, R. E., Gillespie, D. C., Kelly, R. K. (1976). Viruses associated with lymphocystis disease and the dermal sarcoma of walleye (Stizostedion vitreum). J. Fish. Res. Bd Can. 33: 2408-2419

Yoshimizu, M., Nomura, T., Awakura, T., Ezura, Y., Kimura, T. (1989). Prevalence of pathogenic fish viruses in anadromous masu salmon (Oncorbynchus masou) in the northern part of Japan, 1976-1987. Physiol. Ecol. Japan, Spec. Vol. 1. $559-576$

Yoshimizu, M., Tanaka, M., Kimura, T (1987). Oncorhynchus masou virus (OMV): incidence of tumor development among experimentally infected representative salmonid species. Fish Pathol. 22: 7-10

zur Hausen, H. (1980). The role of viruses in human tumors Adv. Cancer Res. 33: 77-107

Manuscript first received: July 29, 1993

Revised version accepted: March 15, 1994 